\title{
Relationships between Blossom-End Rot in Pepper and Calcium Fertilization during the First Fruit Setting Period
}

\author{
Il-Su Byeon, Sun-Young Seo, and Jong-Bae Chung* \\ Division of Life and Environmental Science, Daegu University, Gyeongsan 712-714, Korea
}

\begin{abstract}
Blossom-end rot is probably the most recognizable Ca deficiency that affects fruit production including pepper. We investigated the induction of blossom-end rot during the period of rapid vegetative growth and fruit setting, and the effect of Ca fertilization on the suppression of blossom-end rot in pepper plants grown in a plastic-film house. During the first fruit setting period, more than $60 \%$ of pepper fruits larger than $8 \mathrm{~cm}$ showed the symptoms of blossom-end rot. Under the condition of transpiration occuning at a much faster rate, growing leaves of pepper plants could be the greater sinks for Ca than developing fruits. The incidence of blossom-end rot was significantly decreased after two weeks of Ca fertigation. Calcium application during the rapid vegetative growth and fruit setting period could be suggested as a preventive step to overcome the local Ca deficiency inducing blossom-end rot of pepper fruits.
\end{abstract}

Key words: Blossom-end rot, Calcium, Pepper, Vegetable fruit

\section{Introduction}

Blossom-end rot is the most common physiological disorder found in pepper and tomato. Blossom-end rot is associated with a local calcium (Ca) deficiency during the initial stage of fruit development (Marcelis and Ho, 1999; Morley et al., 1993). Calcium is required in relatively large concentrations for normal cell growth. Calcium is essential for the stability of biomembranes, and Ca-polygalacturonates are required in the middle lamella for cell wall stability (Marschner, 1986). When a rapidly growing fruit is deprived of necessary $\mathrm{Ca}$, necrotic lesions are initially developed at the outer surface of flowering end of the fruit. Plants are susceptible to such localized $\mathrm{Ca}$ deficiencies in low or non transpiring tissues.

The Ca deficiency in plants that causes blossom-end rot is commonly caused by one of the following; lack of $\mathrm{Ca}$ in the soil, periods of drought followed by large amounts of water, over watering, excess nitrogen, and excess competitive cations. Environmental conditions including high temperature and light intensity, water deficit, and high salinity are also known to cause blossom-end rot (Rubio et al., 2009; Saure, 2001.). Under these conditions, a lack of Ca uptake from the soil, a rapid plant growth and fruit development, and a low transpiration of the whole plant may restrict the transfer of $\mathrm{Ca}$ to the low transpiring fruits (Bradfield and Guttridge, 1984; Marcelis and Ho, 1999).

Rapid growth of pepper plants, particularly of those in greenhouse, correlates with lower $\mathrm{Ca}$ absorption from substrates and its lower concentrations in fruits along with induction of blossom-end rot (Marcelis and Ho, 1999). Blossom-end rot develops most frequently when vegetative growth is rapid and fruit setting starts, just as fruits need $\mathrm{Ca}$ the most (Ho et al., 1993).

Under the condition of high temperature in the greenhouse, competition for water between leaves and fruits can restricts $\mathrm{Ca}$ translocation to the low transpiring fruits (Ho et al., 1993). In this study, we examined the induction of blossom-end rot during the period of rapid vegetative growth and fruit setting, and the effect of $\mathrm{Ca}$ fertilization on the suppression of blossom-end rot in pepper plants grown in plasticfilm house.

\footnotetext{
Received : January 6. 2012 Accepted : January 25. 2012

*Corresponding author : Phone: +82538506755

E-mail: jbchung@daegu.ac.kr
} 


\section{Materials and Methods}

The experiment was conducted in a plastic-film house at Experimental Farm of Daegu University. The soil characteristics are shown in Table 1. The house Soil was prepared two weeks before transplanting after application of basal chemical fertilizer (N-P-K=12.2-

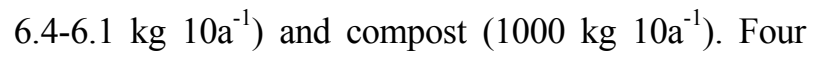
raws spaced $90 \mathrm{~cm}$ apart were prepared in the plasticfilm house $(6.5 \mathrm{~m} \times 25 \mathrm{~m})$. Pepper seedlings (Capsicum annum L., Nocgwang) from a commercial nursery were transplanted on May 4, 2011 in each raw with 40-cm space.

Six plots of ten pepper plants were selected randomly in the plastic-film house, and the incidence of blossomend rot in each plot was examined during the first fruit setting period. Pepper fruits larger than $8 \mathrm{~cm}$ were harvested in each plot, and the ratio of blossom-end rot fruit was calculated. After this investigation, $\mathrm{Ca}$ fertilizer was applied in three of the six plots using water soluble $\mathrm{Ca}$ fertilizer $(4 \% \mathrm{CaO})$ at the rate of $10 \mathrm{~kg}$ per 10a through a drip irrigation system. Two weeks after $\mathrm{Ca}$ fertilization, the effect of $\mathrm{Ca}$ on suppression of blossom-end rot was evaluated by comparing the incidences of blossom-end rot in the pepper plants of $\mathrm{Ca}$ treated and untreated plots. Concentration of $\mathrm{Ca}$ in fruits of normal and blossom-end rot was quantitated by ICP-OES (Varian, model 720-ES, Mulgrave, Australia) after wet digestion in 1:1 $\mathrm{HNO}_{3}-$ $\mathrm{H}_{2} \mathrm{SO}_{4}$ solution.

\section{Results and Discussion}

During the first fruit setting period, more than $60 \%$ of pepper fruits larger than $8 \mathrm{~cm}$ showed the symptoms of blossom-end rot (Table 2). As shown in Fig. 1, the affected area occurred mostly on the sides of the pepper fruits near the blossom end. As the lesion

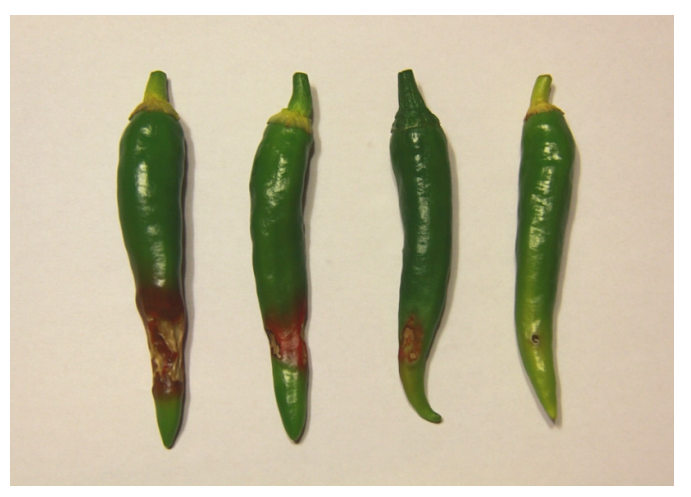

Fig. 1. Blossom-end rot of pepper fruits.

Table 1. Some physicochemical characteristics of the soil used in experiment.

\begin{tabular}{|c|c|c|c|c|c|c|c|c|c|}
\hline \multirow{2}{*}{$\mathrm{pH}$} & \multirow{2}{*}{$\mathrm{EC}_{\mathrm{e}}$} & \multirow{2}{*}{ Organic matter } & \multirow{2}{*}{ Total N } & \multirow{2}{*}{ Avail. $\mathrm{P}_{2} \mathrm{O}_{5}$} & \multicolumn{3}{|c|}{ Exch. Cation } & \multirow{2}{*}{ CEC } & \multirow{2}{*}{ Texture } \\
\hline & & & & & $\mathrm{Ca}$ & $\mathrm{Mg}$ & $\mathrm{K}$ & & \\
\hline$(1: 5)$ & $\mathrm{dS} \mathrm{m}^{-1}$ & $\mathrm{~g} \mathrm{~kg}^{-1}$ & $\mathrm{~g} \mathrm{~kg}^{-1}$ & $\mathrm{mg} \mathrm{kg}^{-1}$ & \multicolumn{5}{|c|}{ 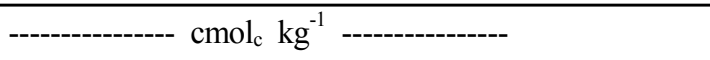 } \\
\hline 6.7 & 3.2 & 26 & 1.7 & 390 & 5.8 & 2.6 & 1.4 & 11.5 & Sandy clay \\
\hline
\end{tabular}

Table 2. The effect of Ca fertilization on suppression of the incidence of blossom-end rot of pepper fruits.

\begin{tabular}{ccc}
\hline \hline \multirow{2}{*}{ Treatment } & \multicolumn{2}{c}{ Incidence of blossom-end rot $^{\dagger}$} \\
\cline { 2 - 3 } & Before $\mathrm{Ca}$ application & After Ca application \\
\hline & $\%$ & $44.3 \pm 6.8$ \\
$+\mathrm{Ca}$ & $64.7 \pm 10.2^{\ddagger}$ & $19.2 \pm 4.5$ \\
\hline
\end{tabular}

${ }^{\dagger}$ Number of blossom-end rot fruits as \% of total number of fruit larger than $8 \mathrm{~cm}$.

${ }^{\ddagger}$ Mean \pm standard deviation.

Table 3. Concentration of $\mathrm{Ca}$ in pepper fruits of normal and blossom-end rot incidence.

\begin{tabular}{ccc}
\hline \hline Nutrient & Normal fruit & Blossom-end rot fruit \\
\hline & $\mathrm{mg} \mathrm{kg}^{-1}$ & $\mathrm{mg} \mathrm{kg}^{-1}$ \\
$\mathrm{Ca}$ & $1632.2 \pm 253.9^{\dagger}$ & $967.8 \pm 97.0$ \\
\hline
\end{tabular}

${ }^{\dagger}$ Mean \pm standard deviation. 
developed, the affected area enlarged and became sunken, resulting in a brown or yellow appearance.

The incidence of blossom-end rot decreased significantly after two weeks of $\mathrm{Ca}$ application. Also in the plots where $\mathrm{Ca}$ was not applied, a significant decrease of blossom-end rot affected fruits was observed, though the decrease was much less than that found in the plots of $\mathrm{Ca}$ fertilization. Considering the significant suppression of blossom-end rot incidence with $\mathrm{Ca}$ fertilization, the high incidence of blossom-end rot in pepper fruits found during the first fruit setting period could be due to $\mathrm{Ca}$ deficiency.

Concentration of $\mathrm{Ca}$ in the blossom-end rot-affected pepper fruits was much lower than that found in the normal fruits (Table 3). The application of $\mathrm{Ca}$ fertilizer led to a significant increase in $\mathrm{Ca}$ concentrations in pepper fruits and suppressed the incidence of blossomend rot.

In this experiment, a very abrupt and extensive occurrence of blossom-end rot in pepper plants was observed during the first fruit setting period, at which vegetative growth of pepper plants was very rapid. Since the transpirational water flow goes to areas of new shoot growth that have the greatest transpirational demand, Ca will therefore be deposited in the new shoot and leaf tissues, and little will end up in developing fruit where it is needed most. In the study of Leibisch et al. (2009), regarding fruit development in tomato, the lowest $\mathrm{Ca}$ concentrations were observed 30 days after anthesis. The $\mathrm{Ca}$ concentrations decreased from 10 to 30 days after anthesis and increased again towards later developmental stages. It has been suggested that blossom-end rot occurs mostly during a period of high cellular $\mathrm{Ca}$ demand, when fruit growth is accelerated or Ca delivery to the fruit is limited (Bradfield and Guttridge, 1984; Ho, 1989; Marcelis and Ho, 1999). During cell expansion, there is a considerable demand for $\mathrm{Ca}$ as a structural component of new cell walls and membranes, and as a cytosolic signal in the form of a counter-cation in the enlarging vacuole (Ho and White, 2005).

The high temperature and dry condition in plasticfilm houses could be another reason of the abrupt blossom-end rot incidence observed in this experiment. Under high temperature and dry weather condition, when transpiration is occurring at a much faster rate, growing leaves and stems of pepper plants could be greater sinks for $\mathrm{Ca}$ than developing fruits. Since the mobility and redistribution of $\mathrm{Ca}$ in the plants are relatively poor, the resulting decrease of $\mathrm{Ca}$ that flows into those young fruit tissues via xylem transport is believed to contribute to the onset of blossom-end rot (Ho et al., 1993). In addition, blossom-end rot could be induced under the restricted $\mathrm{Ca}$ translocation to fruits due to high amounts of competitive cations and restricted water supply in soils and excessive $\mathrm{N}$ fertilization causing a rapid vegetative growth (Adams and Ho, 1993; Bar-Tal, 2001; Taylor et al., 2004).

Recently, several studies have implicated the possibility of $\mathrm{P}, \mathrm{Mn}$ and $\mathrm{Zn}$ nutrition in the induction of blossomend rot of vegetables fruits (Aktas et al., 2005; Silber et al., 2005). Manganese and $\mathrm{Zn}$ are found to suppress blossom-end rot of pepper fruits with inhibition of the production of reactive oxygen species in apoplast. However, a severe water stress which reduces $\mathrm{Ca}$ uptake and distracts $\mathrm{Ca}$ flux from the fruit to the leaves is the most common cause of this physiological disorder of vegetable fruits under high transpiration.

\section{Conclusion}

Blossom-end rot is the most recognizable Ca deficiency that affects vegetable fruit production including pepper. Considering the results of this study and previous trials (Bar-Tal, 2001; Silber et al., 2005; Taylor et al., 2004; Wada et al., 1996), additional Ca application in combination with increased irrigation scheduling during the period of rapid vegetative growth and fruit setting could be suggested as a highly effective preventive measure to overcome the local Ca deficiency inducing blossom-end rot of vegetables fruits.

\section{References}

Adams, P. and L.C. Ho. 1993. Effects of environment on the uptake and distribution of calcium in tomato and on the incidence of blossom-end rot. Plant Soil 154:127-132.

Aktas, H., L. Karni, D.C. Chang, E. Turhan, A. Bar-Tal, and B. Aloni. 2005. The suppression of salinity-associated oxygen radicals production, in pepper (Capsicum annuum) fruit, by manganese, zinc and calcium in relation to its sensitivity to blossom-end rot. Physiol. Plant. 123:67-74.

Bar-Tal, A., J. Oserovitz, B. Aloni, M. Keinan, S. Grantz, A. Hazan, M. Itach, L. Karni, A. Avidan, I. Posalski, and N. Tratkovski. 2001. Relationships between blossom-end rot 
and water availability and $\mathrm{Ca}$ fertilization in bell pepper fruit production. Acta Hort. 554:97-104.

Bradfield, E.G. and C.G. Guttridge. 1984. Effects of night-time humidity and nutrient solution concentration on the calcium content of tomato fruit. Sci. Hort. 22:207-374.

Ho, L.C. 1989. Environmental effects on the diurnal accumulation of ${ }^{45} \mathrm{Ca}$ by young fruit and leaves of tomato plants. Ann. Bot. 63:282-288.

Ho, L.C., R. Belda, M. Brown, J. Andrews, and P. Adams. 1993. Uptake and transport of calcium and the possible causes of blossom-end rot in tomato. J. Exp. Bot. 44: 509-518.

Ho, L.C. and P.J. White. 2005. A cellular hypothesis for the induction of blossom-end rot. Ann. Bot. 95:571-581.

Leibisch, F., J.F.J. Max, G. Heine, and W.J. Horst. 2009. Blossom-end rot and fruit cracking of tomato grown in net-covered greenhouses in Central Thailand can partly be corrected by calcium and boron strays. J. Plant Nutr. Soil Sci. 172:140-150.

Marschner, H. 1986. Mineral nutrition of higher plants. Academic Press, New York, USA.

Marcelis, L.F.M. and L.C. Ho. 1999. Blossom-end rot in relation to growth rate and calcium content in fruits of sweet pepper (Capsicum annuum L.). J. Exp. Bot. 50:357-363.

Morley, P.S., M. Hardgrave, M. Bradley, and D.J. Pilbeam. 1993. Susceptibility of sweet pepper (Capsicum annuиm L.) cultivars in the calcium deficiency disorder "blossom-end rot". p. 561-567. In Fragoso, M.A.C. and Van Beusichem M.L. (ed.) Optimization of plant nutrition. Kluwer Academic Publishers, The Netherlands.

Rubio, J.S., F. Garcia-Sanchez, F. Rubio, and V. Martinez. 2009. Yield, blossom-end rot incidence, and fruit quality in pepper plants under moderate salinity are affected by $\mathrm{K}^{+}$and $\mathrm{Ca}^{2+}$ fertilization. Sci. Hort. 119:79-87.

Saure, M.C. 2001. Blossom-end rot of tomato (Lycopersicon esculentum Mill.) - a calcium- or a stress-related disorder? Sci. Hort. 90:193-208.

Silber, A., M. Bruner, E. Kenig, G. Reshef, H. Zohar, I. Posalski, H. Yehezkel, D. Shmuel, S. Cohen, M. Dinar, E. Matan, I. Dinkin, Y. Cohen, L. Karni, B. Aloni, and S. Assouline. 2005. High fertigation frequency and phosphorus level: Effects on summer-grown bell pepper growth and blossom-end rot incidence. Plant Soil 270:135-146.

Taylor, M.D., S.J. Locascio, and M.R. Alligood. 2004. Blossomend rot incidence of tomato as affected by irrigation qualtity, calcium source, and reduced potassium. Hortscience 39:11101115 .

Wada, T., H. Ikeda, M. Ikeda, and H. Furukawa. 1996. Effect of foliar application of calcium solution on the incidence of blossom-end rot of tomato fruit. J. Jpn. Soc. Hort. Sci. 65:553-558 